Boletín de la Sociedad Geológica Mexicana

VOLUMEN 65, NÚM. 2, 2013, P. 213-217

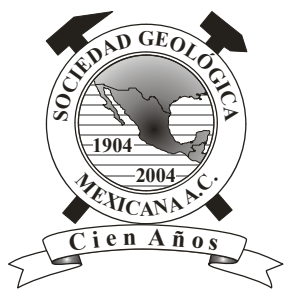

\title{
Squilla taulinanus n. sp. (Crustacea, Stomatopoda, Squillidae) from the Burdigalian (Miocene) of Taulignan, south-eastern France
}

\author{
Shane T. Ahyong ${ }^{1, *}$, Sylvain Charbonnier ${ }^{2, * *}$, Alessandro Garassino ${ }^{3, * * *}$ \\ ${ }^{1}$ Department of Marine Invertebrates, Australian Museum, 6 College Street, Sydney NSW 2010, Australia, and School of Biological, \\ Environmental and Earth Sciences, University of New South Wales, NSW 2052, Australia. \\ ${ }^{2}$ Muséum National d'Histoire Naturelle, Paris, Département Histoire de la Terre, UMR 7207 CNRS, Centre de Recherche sur la \\ Paléobiodiversité et les Paléoenvironnements, Case postale 38, 8 rue Buffon, F-75005 Paris (France). \\ ${ }^{3}$ Museo di Storia Naturale di Milano, Sezione di Paleontologia, Corso Venezia 55, 20121 Milano (Italia). \\ *shane.ahyong@austmus.gov.au \\ *** scharbonnier@mnhn.fr \\ ***alegarassino@gmail.com
}

\begin{abstract}
Mantis shrimps (Crustacea: Stomatopoda) are rather rare in the fossil record. Nineteen species have been assigned to Squillidae, of which 12 species have been recorded from the Miocene. We describe herein a squillid, Squilla taulinanus $\mathrm{n}$. sp., from the Miocene of Taulignan, south-eastern France. The exceptionally well-preserved specimen is remarkable in apparently having abdominal somites 5-6 conjoined; such somatic abnormality is rare in stomatopods. A taxonomic reassessment of the fossil species assigned to Squilla is provided.
\end{abstract}

Keywords: Crustacea, Stomatopoda, Squillidae, Burdigalian, Miocene, France.

\section{Resumen}

Las mantis marinas (Crustacea: Stomatopoda) son raros en el registro fósil. Diecinueve especies han sido asignadas a Squillidae, de las cuales 12 especies se registran en el Mioceno. Se describe aqui el esquílido, Squilla taulinanus $n$. sp., del Mioceno de Taulignan, sureste de Francia. El ejemplar excepcionalmente bien preservado es notable por aparentemente presentar las somitas abdominales 5-6 conjuntas; esta anomalía somática es rara en los estomatópodos. Se presenta una reevaluación taxonómica de las especies fósiles asignadas a Squilla.

Palabras Clave: Crustacea, Stomatopoda, Squillidae, Burdingaliano, Mioceno, Francia.

\section{Introduction}

The mantis shrimps, Order Stomatopoda Latreille, 1817, are well known as highly efficient predators with remarkably developed vision and for their second maxillipeds modified into powerful raptorial claws. The crown-group stomatopods belong to Verunipeltata Haug et al., 2010, with almost 500 extant species arrayed in seven superfamilies, the largest of which is Squilloidea Latreille, 1802. The verunipeltatan fossil record, however, is sparse, with fewer than 40 fossil species known in total and 12 named species recorded from the Miocene. At present, 19 fossil species are assigned to the Squillidae (Ahyong et al., 2007; De Angeli and Beschin, 2006; Schram, 2010), of which eight fossil species 
are assigned to Squilla Fabricius, 1787: Squilla angolia (Berry, 1939) (Eocene, Angola); Squilla breoniensis De Angeli and Beschin, 2006 (middle Eocene, Italy); Squilla cretacea (Schlüter in von der Marck and Schlüter, 1868) (Late Cretaceous, Germany); Squilla empusa Say, 1818 (Pleistocene to recent, North America); Squilla hollandi Förster, 1982 (late Eocene, Germany); Squilla laingae Hof and Schram, 1998 (Miocene of California); Squilla miocenica Lovisato, 1894 (Miocene, Italy and Spain); and Squilla sonomana (Rathbun, 1926) (Pliocene, California). In the present paper, we describe a new species of Miocene squillid from the Burdigalian of France, and reassess the taxonomic placement of fossil species assigned to Squilla.

\section{Materials and Methods}

The specimen derives from Miocene (Burgidalian) marine strata at Taulignan (La Croix de Bouchet), Drôme department, France. It is preserved in dorso-ventral aspect and comprises a part and counterpart in which details of the dorsal and ventral surfaces are preserved. Morphological terminology follows Ahyong (2001, 2012). Total length (TL), measured from the rostral tip to the submedian teeth of the telson, is estimated for the specimen owing to its incompletely preserved posterior telson. Carapace length (CL) is measured along the dorsal midline and excludes the rostral plate. The holotype is deposited in the Collection de Paléontologie, Muséum National d'Histoire Naturelle, Paris $(\mathrm{MNHN})$. Measurements are in millimeters (mm).

\section{Systematic palaeontology}

Order Stomatopoda Latreille, 1817

Superfamily Squilloidea Latreille, 1802

Family Squillidae Latreille, 1802

Genus Squilla Fabricius, 1787

Type species. Cancer mantis Linnaeus, 1758, by designation under the plenary powers I.C.Z.N. (1945: Opinion 186).

\section{Squilla taulinanus n. sp.} Figure 1

Holotype. MNHN.F.A42046, TL estimated at $100 \mathrm{~mm}$, CL $20 \mathrm{~mm}$.

Type locality. Taulignan (La Croix de Bouchet), Drôme department, southeastern France.

Type age. Burdigalian (Miocene).

Etymology. From Taulinanus, a Roman patrician from which the modern name of the Taulignan locality is derived; used as a noun in apposition.

Diagnosis. Rostral plate longer than wide, apex rounded; carapace anterolateral margins sloping posteriorly; median carina with uninterrupted anterior bifurcation, base of bifurcation near midpoint between base of rostral plate and dorsal pit; intermediate, lateral and reflected marginal carinae distinct, well developed; posterolateral margin obtusely angled. Thoracic somite 5 (pereonite 5) lateral process a simple straight, evenly tapering spine, directed anterolaterally; thoracic somite 6-7 lateral processes triangular, anterior margin sinuous with low lobe anteriorly; thoracic somite 6-8 and abdominal somites (pleonites) with distinct submedian carinae. Telson without accessory median carinae; prelateral lobe as long as carina of lateral primary tooth, with blunt, angular apices.

Description. Eye large, not extending beyond antennular peduncle segment 1 (Figure 1A, B). Short, subquadrate ocular scales, inclined anteriorly. Short triangular antennular somite dorsal processes, directed anterolaterally. Antennular peduncle segments subequal in length, total length shorter than carapace. Antennal peduncle reaching beyond midlength but not apex of antennular peduncle segment 1; article 2 and 3 subequal in length. Antennal scale about $0.4 \mathrm{CL}$. Antennal protopod (= coxa + basipod) unarmed.

Rostral plate longer than wide, apex rounded. Carapace with short but distinct anterolateral spines; anterolateral margins sloping posteriorly; gastric and cervical grooves distinct; median carina with uninterrupted anterior bifurcation, base of bifurcation near midpoint between base of rostral plate and dorsal pit; intermediate carinae extending posteriorly beyond carapace midlength; lateral and reflected marginal carinae distinct, well developed. Lateral carina extending for full length of carapace. Posterolateral margin obtusely angled. Posterior margin unarmed, faintly biconcave.

Thoracic somite 5 (pereonite 5) lateral process a simple straight, evenly tapering spine, directed anterolaterally (Figure 1C). Thoracic somite 6-7 lateral processes triangular, anterior margin sinuous with low lobe anteriorly. Thoracic somite 6-8 with distinct submedian, intermediate and lateral carinae.

Right pereopods 1-3 preserved, folded laterally across respective thoracic somites, length about equal to corresponding somite width.

Abdominal somites (pleonites) with distinct submedian, intermediate lateral and marginal carinae; submedian carinae on somites 1-3 subparallel, slightly divergent on posterior 2 somite, unarmed on somites 1-4, possibly posteriorly armed on last somite; intermediate and lateral carinae of posterior four somites apparently with broken posterior apices. Abdominal somite 1 pleural plate anteriorly rounded. Specimen aberrant, with somites 5 and 6 apparently conjoined, somite demarcation not evident dorsally, but evident ventrally by juxtaposition of abdominal somite 5 pleopod insertions and abdominal somite 6 sternite; somite 6 sternite posteriorly unarmed (Figure 1D).

Telson incomplete. Dorsal surface with strong median carina, interrupted proximally; accessory median carinae absent; dorsolateral surface with curved rows of shallow 

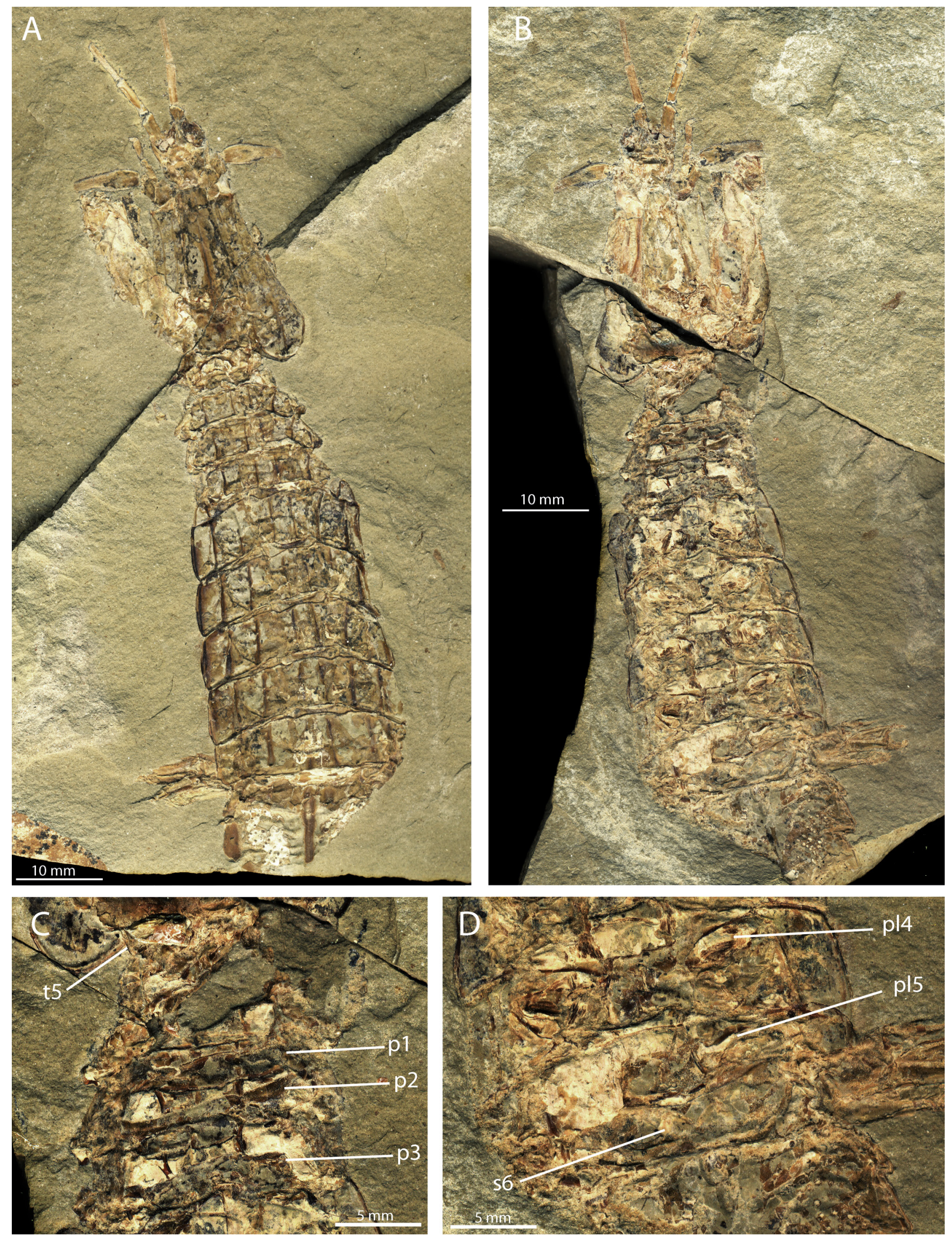

Figure 1. Squilla taulinanus n. sp. from the Miocene (Burdigalian) of Taulignan, Drôme department, France. A-B, holotype MNHN.F.A42046, complete specimen in dorsal and ventral views. C, detail of the lateral process of thoracic somite 5, ventral view and pereopods $1-3$. D, detail of the conjoined abdominal somites 5 and 6, ventral view. Abbreviations: $\mathrm{s} 6=$ abdominal somite $6 ; \mathrm{p} 1-3=$ pereopods $1-3$; p14-5 = pleopod $4-5$ insertion; $5=$ lateral process of thoracic somite 5. Photos: P. Loubry and C. Lemzaouda 
pits; prelateral lobe as long as carina of lateral primary tooth, both swollen and with blunt, angular apices.

Uropodal protopod (basipod) with two terminal spines, inner longer than outer, ventrally carinate, broken distally; exopod proximal segment partially preserved; endopod slender, curved.

Comments. Squilla taulinanus n. sp. is the ninth species of fossil stomatopod to be assigned to Squilla. A significant amount of detail is preserved in the holotype of $S$. taulinanus, including the rostral plate, ocular scales, antennules, antennae, carapace carinae, pereopods, thoracic and abdominal carinae. Unfortunately, the dactyli of the raptorial claws and much of the telson and uropods, each of which carry important diagnostic information, are absent. The combination of remaining characters, however, indicates that it belongs to Squilla: the lateral processes of thoracic somites 5-7 are single, rather than bilobed, the carapace has a full complement of carinae, the posterolateral angle of the carapace is obtusely angular (as in most species of Squilla) and the thoracic and abdominal somites have prominent submedian carinae. The swollen carinae on the margins of the telson indicate that the specimen is probably a male.

The specimen is remarkable in apparently having abdominal somites 5-6 conjoined. In dorsal view, only five somites are evident, rather than six. The first somite is clearly identifiable by the presence of the pleural plate, and the last somite is evident by its associated uropod. The tergite of the conjoined somite 5-6, however, has the appearance of a typical somite 5 , in having four pairs of carinae instead of three (submedian, intermediate, lateral), submedian carinae that are in line with those of the preceding somite, and straight intermediate carinae that are subparallel with the submedian carinae. Normally, the sixth abdominal somite lacks the marginal carinae as an accommodation for the uropod, the submedian carinae are placed more medially than those on the first somite, and the intermediate carinae are always divergent anteriorly where they join a short oblique carina that extends to the articular condyle on the anterior margin of the tergite near the base of the lateral carinae. This arrangement is not present on the last abdominal somite of the Taulignan specimen. Moreover, this is not a taphonomic artefact as the articulations between each somite are well preserved and intact. In ventral aspect, however, evidence of all six somites can be discerned. Stomatopoda have five pairs of pleopods (one pair each on somites 1-5), and the uropods on somite 6 , separated by a broad, flat sternal plate. The ventral aspect of the specimen shows five sets of pleopod insertions with their associated sternite, and the sternal plate of somite 6 . The fifth and sixth sternites, however, appear to be appressed and are apparently conjoined or fused. Thus, the somite demarcation is not apparent in dorsal aspect, but ventrally is well marked. Manning (1962) reported partial, asymmetrical conjoint thoracic somites 6 and 7 in Squilla bigelowi Schmitt, 1940, but such somatic abnormalities are rare in stomatopods.
The conjoined abdominal somites in $S$. taulignanus are thus all the more unusual in being symmetrical. Despite its symmetry, however, we regard the conjoined somites in $S$. taulignanus as an abnormality because the species is clearly recognisable as a species of Squilla and such fusion is not known in any other stomatopod. Moreover, the 'crowding' of the sternites of the last two abdominal somites, in addition to the complete pleuron with marginal carinae on the last abdominal somite, could have probably restricted full movement of the uropod, suggesting an abnormal condition

Discussion. Squilla taulinanus n. sp. can be distinguished from the eight other fossil species previously assigned to Squilla as follows:

- Squilla angolia differs from S. taulinanus n. sp. in the much longer prelateral lobe and the presence of accessory median carinae on the telson;

- Squilla breoniensis is readily separated from $S$. taulinanus n. sp. by lacking abdominal submedian carinae. Furthermore, S. breoniensis appears to lack a median carina on the carapace and has four or five teeth on the dactylus of the raptorial claw; it does not belong to Squilla but may instead be closely related to members of the "Meiosquilla group" in Squillidae (Ahyong, 2005);

- Squilla cretacea is a poorly known species. The minimal original description and crude figure of the holotype (Schlüter in von der Marck and Schlüter, 1868: pl. 54, fig. 7), however, show a lysiosquilloid-like non-carinate carapace and about nine teeth on the dactylus of the raptorial claw. This indicates that Schlüter's species represents neither Squilla nor Squilloidea and is more likely to belong to the Lysiosquilloidea or Eurysquilloidea;

- Squilla empusa is readily separable from $S$. taulinanus n. sp. by the longer anterolateral spines on the carapace, reaching anteriorly slightly beyond the base of the rostral plate (rather than falling well short) and the wider than long rostral plate (rather than longer than wide), as well as the position of the base of the anterior bifurcation of the median carina of the carapace (much closer to the dorsal pit than anterior margin of the carapace);

- Squilla hollandi has median carinae on the thoracic and abdominal somites, absent in S. taulinanus n. sp.;

- Squilla sonomana differs from S. taulinanus $\mathrm{n}$. sp. by the fully rounded, rather than obtusely angular, posterolateral margin of the carapace;

- Squilla laingae has weakly developed instead of prominent submedian carinae on the abdomen, and lacks submedian denticles on the telson. Unfortunately, the cephalothorax of Squilla laingae is not presently known, but based on telson shape and apparent absence of submedian denticles on the telson, Squilla laingae might be closer to Pterygosquilla Hilgendorf, 1890, than Squilla Fabricius, 1787 ;

- Squilla miocenica is known only from the dactylus of the raptorial claw, but given that it is eight-toothed, it is unlikely to represent Squilla, whose known species have six dactylar teeth. 
Of the extant species of Squilla, S. taulinanus n. sp. most closely approaches Squilla brasiliensis Calman, 1917, and S. caribaea Manning, 1969, both from the western Atlantic, in sharing a distally rounded rostral plate, distinct anterior bifurcation of the median carina of the carapace that is not interrupted at the base, an obtusely angular posterolateral margin of the carapace and lateral processes of thoracic somites 6-7 that have a low lobe or swelling on the anterior proximal margin. The new species can be separated from $S$. caribaea by the distinctly sloping anterolateral margins of the carapace (almost transverse in S. caribaea) and position of the base of the anterior bifurcation of the median carina of the carapace (almost equidistant from dorsal pit anterior margin of carapace versus about two-thirds of distance from anterior margin of carapace to dorsal pit). From $S$. brasiliensis, S. taulinanus n. sp. can be separated by its straight, rather than falcate lateral process of thoracic somite 5 .

\section{Acknowledgements}

We gratefully acknowledge Christian Lemzaouda and Philippe Loubry (MNHN, Paris) for assistance in photographic work, and Caroline Haug (University of Greifswald, Germany) and Lothar Schöllmann (Museum für Naturkunde, Münster, Germany) for constructive reviews of the manuscript. This paper is a contribution from the Museo di Storia Naturale di Milano (Paleontology Department), the UMR CNRS 7207 Centre de Recherche sur la Paléobiodiversité et les Paléoenvironnements as well as the Département Histoire de la Terre (MNHN, Paris), and the Australian Museum, Sydney.

\section{References}

Ahyong, S.T., 2001, Revision of the Australian Stomatopod Crustacea: Records of the Australian Museum, 26, 1-326.

Ahyong, S.T., 2005, Phylogenetic analysis of the Squilloidea (Crustacea: Stomatopoda): Invertebrate Systematics, 19, 189-208.

Ahyong, S.T., 2012, The marine fauna of New Zealand: mantis shrimps (Crustacea: Stomatopoda): NIWA Biodiversity Memoir, 125, 1-111.

Ahyong, S.T., Garassino, A., Gironi, B., 2007, Archaeosculda phoenicia n. gen., n. sp. (Crustacea, Stomatopoda, Pseudosculdidae) from the Upper Cretaceous (Cenomanian) of Lebanon: Atti della Società italiana di Scienze naturali e del Museo civico di Storia naturale in Milano, 148, 3-15.

Berry, C.T., 1939, A summary of the fossil Crustacea of the Order Stomatopoda, and a description of a new species from Angola: American Midland Naturalist, 21, 461-471.

Calman, W.T., 1917, Crustacea. Part IV. Stomatopoda, Cumacea, Phyllocarida, and Cladocera. British Antarctic ("Terra Nova") Expedition, 1910: Natural History Report Zoology, 3, 137-162.
De Angeli, A., Beschin, C., 2006, Stomatopodi Terziari del Veneto (Italia Settentrionale): Montecchio Maggiore, Vicenza, Italia, Studi e Ricerch, Associazione Amici del Museo, Museo Civico "G. Zannato", Boletín, 13, 25-34.

Fabricius, J.C., 1787, Mantissa insectorum sistens eorum species nuper detectas: adjectis characteribus genericis, differentiis specificis, emendationibus, observationibus: Proft Hafniae, 1, 1-348.

Förster, R., 1982, Heuschreckenkrebse (Crustacea: Stomatopoda) aus dem Alttertiär von Helmstedt und Handorf (Niedersachsen) und der Oberkreide von Nigeria: Neus Jahrbuch für Geologie und Paläontologie Monatshefte, 6, 321-335.

Haug, J., Haug, C., Maas, A., Kutschera, V., Waloszek, D., 2010, Evolution of mantis shrimps (Stomatopoda, Malacostraca) in the light of new Mesozoic fossils: BMC Evolutionary Biology 10, 290-316.

Hilgendorf, F., 1890, Eine neue Stomatopoden-Gattung Pterygosquilla: Sitzungsberichte der Gesellschaft naturforschender Freunde zu Berlin, 1890, 172-177.

Hof, C.H.J., Schram, F.R., 1998, Stomatopods (Crustacea: Malacostraca) from the Miocene of California: Journal of Paleontology, 72, $317-331$.

International Comission on Zoological Nomencalture (I.C.Z.N.), 1945, Opinion 186: suspension of the rules for Squilla Fabricius (J.C.), 1787 (Class Crustacea, Order Stomatopoda): Opinions and declarations rendered by the International Commission on Zoological Nomenclature, 3, 53-64.

Latreille, P.A., 1802, Histoire naturelle, générale et particulière, des Crustacés et des Insectes 3 : Paris, France, F. Dufart, 467 pp.

Latreille, P.A., 1817, Les crustacés, les arachnides et les insectes, in Cuvier, G. (ed.), Le Règne animal distribué d'après son organisation, pour servir de base à l'histoire naturelle des animaux et d'introduction à l'anatomie comparée, 1ère édition : Paris, France, Déterville, 31, $653 \mathrm{p}$.

Lovisato, D., 1894, Avanzi di Squilla nel miocene medio di Sardegna : Atti della Reale Accademia dei Lincei, 3, 205-209.

Manning, R.B., 1962, A striking abnormality in Squilla bigelowi Schmitt (Stomatopoda): Crustaceana, 4, 243-244.

Manning, R.B., 1969, Stomatopod Crustacea of the western Atlantic: Studies in Tropical Oceanography, 8, 1-380.

Rathbun, M.J., 1926, The fossil stalk-eyed Crustacea of the Pacific slope of North America: United States National Museum Bulletin, 138, $1-155$.

Say, T., 1817-1818, An account of the Crustacea of the United States: Journal of the Academy of Natural Sciences of Philadelphia, 1(1-2), 57-63, 65-80 (plate 4), 97-101, 155-160, 161-169 (all for 1817), 235-253, 313-316, 374-380, 381-401, 423-441 (all for 1818).

Schmitt, W.L., 1940, The stomatopods of the west coast of America, based on collections made by the Allan Hancock Expedition, 1933-38: Allan Hancock Pacific Expeditions, 5, 129-225.

Schlüter, C., 1868, Crustaceen, in Marck, W., von der, Schlüter, C., Neue Fische und Krebse aus der Kreide von Westphalen (eds.): Palaeontographica, 15, 269-305.

Schram, F.R., 2010, Catalog of the Fossil and Recent Stomatopoda: Langley, Washington, U.S.A., Bay Ridge Press, 294 p.

Manuscript received: September 14, 2012.

Corrected manuscript received: November 14, 2012.

Manuscript accepted: November 14, 2012. 